\title{
Left Anterior Descending Septal Perforator Artery
}

National Cancer Institute

\section{Source}

National Cancer Institute. Left Anterior Descending Septal Perforator Artery. NCI

Thesaurus. Code C102313.

The arteries that arise from the left anterior descending (LAD) artery that supply the interventricular septum. 